\title{
A Note to Our Readers
}

This issue inaugurates a new phase of Sartre Studies International: for the first time, we are publishing articles in French as well as English. This broadens the range of our contributors and our readers. Our French-language contributors in this issue come from France and Belgium; in future, we expect French-language articles from Italy, Quebec and other francophone countries. In short, our journal has become even more international. We find this an exciting new development. Sartre, after all, wrote in French, and there is a considerable body of scholarship in French concerning his work. More than this, we think that you will find that the style and approach of French-language scholars differs appreciably from that of most Englishspeaking scholars. By opening our pages to submissions in French, we are able to include a greater diversity of our approaches to Sartre studies.

In this issue, we have included English translations of the French abstracts and keywords. In future, we plan to include French translations of English abstracts and keywords, making the journal more bilingual.

Finally, almost all the articles in the current issue are from young scholars who bring a fresh perspective. Their work is a testament to the ongoing vitality of Sartre's work.

\section{Aux lecteurs et lectrices}

Ce numéro marque une nouvelle étape de notre revue : pour la première fois, la revue contient des articles en français. Nous nous réjouissons du fait que cela nous permet d'élargir le champ de nos collaborateurs et de nos lecteurs/lectrices. Nos collaborateurs et collaboratrices francophones dans ce numéro viennent de France et de Belgique ; à l'avenir, nous nous attendons à publier des auteurs québécois, italiens, suisses, sans parler d'autres pays francophones. Ainsi la revue est devenue plus « internationale » que jamais. Nous accueillons ce nouveau développement avec un grand enthousiasme.

Dans ce numéro, nous avons inclus des traductions en anglais des résumés et des mots-clefs en français. Nous voulons également inclure des traductions françaises des résumés et des mots-clefs en anglais dans les numéros à venir.

Un dernier mot : presque tous les articles qui paraissent dans ce numéro ont été écrits par de jeunes auteurs qui donnent à la revue un nouvel élan : c'est une attestation de la vitalité contemporaine de l'œuvre de Sartre à l'époque contemporaine.

The Editors

Bruce Baugh

Jean-Pierre Boulé

David Detmer

Sarah Richmond 